
てや小增加を示し，䐋水によりて比重が低下゙すること があきらかとなつた。膨脹は $1000^{\circ} \mathrm{C}$ 加熱物が最も小さ く, $800^{\circ} \mathrm{C}$ まで憢成物ではまだ絹雲母の性質があき らかル見られ，X線の結果と類似する。しかして $1200^{\circ}$ 〜 $1250^{\circ} \mathrm{C}$ に燒成したるのではクリストバライトの転 移が認められるが, $1300^{\circ} \mathrm{C}$ でとれが消えてがラス になる。この関係は塩原と村上とではや小異なりてく るのは，村上粘土中に極く微細な不英が混在するため である。可塑性は制合に大きいが, 絹雲母の特長は最
高の可塑值を示す水分範䧃が広いことである。 絹雲母一珪石䒺では，特に陶石の熱的性質の基本概 念を得るために行つたものである。使用原料は浘原セ リサイト，福島珠石および別府白土で，各成分柔につ いて, 加熱による燒結の状態を追求し, 更に高溫の粘 性水和膨脹等をるしらべた。特に著しいことは珪酸原 料の種類によつて燒結の状態が異なることで,このこ とは陶石を構成する絹雲母のみならず，珪石の種類も 重要な役目をすることである。

\title{
12. $\mathrm{BeO}-\mathrm{Al}_{2} \mathrm{O}_{3}-\mathrm{SiO}_{2}$ 系の研究
}

東京工業大学 ○田賀井秀夫-毛利純一

$\mathrm{BeO}$ 系の耐火物は, 近年ガスタービンのブレイド 等いろいろの方面で関心を持たれているが，その基碟 的研究として $\mathrm{BeO}-\mathrm{Al}_{2} \mathrm{O}_{3}-\mathrm{SiO}_{2}$ 柔の研究を行つた。 今回は $\mathrm{BeO}$ の余り多くない部分について, その平衡 状態の一部を調へたのでと々に報告する。

1) Beryl, $\mathrm{Al}(\mathrm{OH})_{3}, \mathrm{Mg}(\mathrm{OH})_{2}$ 混合物を憢成し てその生成鉱物を決定すること。

Beryl 50 10\%, $\mathrm{Al}(\mathrm{OH})_{3}$ 50 90\%, $\mathrm{Mg}(\mathrm{OH})_{2}$ 0 10\% の範囲の試料を調合し, $1500^{\circ} \mathrm{C}$ て燒成してX 線的に生成鉱物の決定を行つた。Beryl 3ReO- $\mathrm{Al}_{1}, \mathrm{O}_{3}$ . $6 \mathrm{SiO}_{2}$ は $\mathrm{BeO}, \mathrm{SiO}_{2}$ 源としてであり, $\mathrm{Al}(\mathrm{OH})_{3}$ ほ $\mathrm{Al}_{2} \mathrm{O}_{3}$ 源としてである。水酸化物を用いたのは反 応促進のためであり, 叉 $\mathrm{Mg}(\mathrm{OH})_{2}$ も同樣の意図で 用いた。 X線的に調べた結果は混合の割合によりCorundum, Mullite, Berylia, Crysoberyl, Quartz, Cristobalite 等が生成していることがわかつた。すな わち, 場合によりては Berylia $\mathrm{BeO}$ が游離する。な お $\mathrm{Mg}(\mathrm{OH})_{2}$ の割合が多くなると, 各鉣物の生成が 困難になりて来るよ5である。

2) $\mathrm{Beryl}, \mathrm{Al}_{2} \mathrm{O}_{3}$ の混合物を燒成してその生成鉱 物を涣定すること。

Beryl 60 10\%, $\mathrm{Al}_{2} \mathrm{O}_{3}$ 40 90\% の範围の試料を 調合し, $1600^{\circ} \mathrm{C}$ に燒成して前と同梯にX線的に生成 鉱物の決定を行つた。今度は水酸化物を用いるととを やめ, 又 $\mathrm{Mg}(\mathrm{OH})_{2}$ 效果が認められなからたので 使用しなかつた。X線的济調べ結果は，鉱物の生成 状態が 1) の場合よりよいととの他は，1)とほとんど
同樣であつた。

3) $\mathrm{BeO} \cdot 3 \mathrm{Al}_{2} \mathrm{O}_{3}$ について。

以上の実験で, $\mathrm{BeO} \cdot 3 \mathrm{Al}_{2} \mathrm{O}_{3}$ (Jour. Amer. Cer. Soc., 1949, P.26) が現われないので, その存否およ び存在するとすれば, $\mathrm{SiO}_{2}$ とどのよ5に反応するか につき調ベた。

Beryl K $\mathrm{Al}_{2} \mathrm{O}_{3}$ を加えるとをとの㓶合を Berylia と Mullite になるよ5にしたのと, Crysoberyl と Mullite になるよ5にしたのと; $\mathrm{BeO} \cdot 3 \mathrm{Al}_{2} \mathrm{O}_{3}$ と Mullite になるよ5にしたのと 3 種類の試料を調合し て, やはり $1600^{\circ} \mathrm{C}$ : 燒成して, その生成鉱物を調 べたところ, $\mathrm{BeO} ・ 3 \mathrm{Al}_{2} \mathrm{O}_{8}$ の現われる豫想のるのの みが, 预想に違つて Corundum, Mullite, Quartz のほかに X線的には强い線が出なかつた。

次化 $\mathrm{BeCO}_{3}, \mathrm{Al}_{2} \mathrm{O}_{3}$ を用いて $\mathrm{BeO} \cdot 3 \mathrm{Al}_{2} \mathrm{O}_{3}$ を合 成しよ5とし, その割合に混合して, 酸素一都市ガ ス バーナーで熔融した試料をX線的に調べると，今度は あさらかた $\mathrm{BeO} \cdot 3 \mathrm{Al}_{2} \mathrm{O}_{3}$ が生成された。

$\mathrm{BeCO}_{3}, \mathrm{Al}_{2} \mathrm{O}_{3}$ を $\mathrm{BeO} \cdot 3 \mathrm{Al}_{2} \mathrm{O}_{3}$ の割合に調合し それに $\mathrm{SiO}_{2}$ をいろいろの割合に加えた試料をつくつ て,やはり酸素一都市ガスバーナーで熔融して, 生成 鉣物をX線的に調べると， $\mathrm{SiO}_{2}$ の割合が增して行く に琁つて， $\mathrm{BeO} \cdot 3 \mathrm{Al}_{2} \mathrm{O}_{3}$ の線は薄くなり，ある割合 澾すると完全に消失す各。すなわち $\mathrm{BeO} \cdot 3 \mathrm{Al}_{2} \mathrm{O}_{3}$ は $\mathrm{SiO}_{2}$ によりて分解されることがあきらかになつ たo

\section{3. 松土珪酸質害業製品の組成鉱物のX線的研究}

\section{$\mathbf{G} \cdot \mathbf{M} \mathbf{X}$ 線分光器による定量分析の試み}

\author{
東京工業大学山田久夫・○岩井津一・杉浦孝三・宇田川重和
}

